\title{
Phase II placebo-controlled study of nepafenac ophthalmic suspension $0.1 \%$ for postoperative inflammation and ocular pain associated with cataract surgery in Japanese patients
}

\author{
Jiro Numaga
}

Received: 26 January 2011 / Accepted: 21 July 2011 /Published online: 20 September 2011

(C) The Author(s) 2011. This article is published with open access at SpringerLink.com

\begin{abstract}
Objective This study aimed to examine the efficacy and safety of nepafenac ophthalmic suspension compared to placebo in the management of postoperative inflammation and ocular pain in Japanese patients undergoing cataract surgery.

Methods This was a multicenter, randomized, doublemasked, placebo-controlled clinical study. Patients received nepafenac or placebo TID beginning 1 day before cataract surgery and continuing on the day of surgery for 14 days. One additional drop was administered on the day of surgery. The primary efficacy variables were the percentage of patients cured at postoperative day 14 visit (cure defined as aqueous cells score+aqueous flare score $=0$ ) and the percentage of patients who were pain free at all postoperative visits.

Results The cure rate on day 14 after surgery was $71.4 \%$ (75/ $105)$ in the nepafenac group and $28.6 \%(30 / 105)$ in the placebo group, showing a significant difference in cure rate between groups. The nepafenac group demonstrated higher cure rates than those in the placebo group, with a significant difference in cure rate on days 7 and 14 postoperatively. The ocular pain-free rate was $96.2 \%(102 / 106)$ in the nepafenac group and $67.6 \%(71 / 105)$ in the placebo group, showing a significant difference between groups. Concerning adverse events (AEs), 26 AEs were reported in 21 subjects (19.6\%) in the nepafenac group and 31 AEs were reported in 24 subjects $(22.4 \%)$ in the placebo group.
\end{abstract}

\footnotetext{
J. Numaga $(\bowtie)$

Department of Ophthalmology,

Tokyo Metropolitan Geriatric Hospital,

35-2 Sakae-cho,

Itabashi-ku, Tokyo 173-0015, Japan

e-mail: jnumaga@mub.biglobe.ne.jp
}

Conclusion Nepafenac ophthalmic suspension is a nonsteroidal anti-inflammatory drug effective in the prevention of postoperative inflammation and ocular pain associated with cataract surgery.

Keywords Japanese · Nepafenac · Placebo control · Postoperative inflammation $\cdot$ Ocular pain

\section{Introduction}

Nepafenac is a nonsteroidal anti-inflammatory drug (NSAID) and a prodrug that is metabolized into its active form, amfenac, following ocular administration. Delivering amfenac as a prodrug permits increased corneal penetration and high aqueous concentration of the compound [1]. Amfenac suppresses prostaglandin production by inhibiting cyclooxygenase (COX), as do other NSAIDs [1]. Following the administration of diclofenac, total prostaglandin production by the rabbit iris-ciliary body was inhibited by approximately $40 \%$ within $5 \mathrm{~min}$ and remained unchanged thereafter, while nepafenac exhibited an inhibitory effect on prostaglandin production between 5 and $10 \mathrm{~min}$ after administration, with the inhibitory rate exceeding $90 \%$ between 40 and $80 \mathrm{~min}$ after administration [2]. The inhibitory effect of nepafenac on extravascular protein exudation into the aqueous humor of the rabbit continued for $8 \mathrm{~h}$ after administration while diclofenac inhibited vascular permeation up to $4 \mathrm{~h}$ after administration but exhibited no significant inhibitory effect $8 \mathrm{~h}$ after administration [2]. Since its launch in the USA in 2005, nepafenac $0.1 \%$ has been widely used in clinical practice in more than 70 countries worldwide.

To receive marketing approval for the drug in Japan, we conducted a placebo-controlled, multicenter trial to evaluate 
the efficacy and safety of the drug in the management of postoperative inflammation and ocular pain in Japanese patients undergoing cataract surgery with phacoemulsification and aspiration (PEA).

\section{Materials and methods}

Study drug

Nepafenac ophthalmic suspension containing $1 \mathrm{mg}$ of nepafenac (Fig. 1) per $1 \mathrm{ml}$ and placebo with the same formulation as nepafenac suspension excluding nepafenac ingredient supplied in identical, opaque 5-ml bottles.

\section{Study design}

This was a multicenter, randomized, double-masked, placebo-controlled study conducted at 11 Japanese sites (Table 1) from August 2006 to December 2006. This study was conducted in accordance with the Declaration of Helsinki with approval from the institutional review boards. Patients were randomly assigned to receive nepafenac or placebo. Patients instilled one drop in the operative eye three times a day. They began dosing 1 day before surgery and continued on the day of surgery and for 14 days thereafter. On the day of surgery, an additional dose was administered before surgery. The use of other NSAIDs and steroids were prohibited. The test drugs are blinded to the investigators and subjects except for the appointed controller of study drugs.

\section{Subjects}

Patients 20 years of age or older scheduled to undergo cataract extraction by PEA and implantation of an intraocular lens (IOL) were eligible for the study. Each patient was given sufficient explanation about the purpose and details of the study and provided written consent to participate in the study. Patients were excluded from enrollment if they used topical ocular or systemic steroids within 14 days of surgery or used topical ocular or systemic NSAIDs within 7 days of surgery, except an allowed daily dose of low-dose aspirin. Patients were also excluded if they planned to have cataract surgery in their fellow, non-study eye before the 14-day postoperative study visit or had any

Fig. 1 Chemical structure of nepafenac<smiles>NC(=O)Cc1cccc(C(=O)c2ccccc2)c1N</smiles>

Table 1 Investigators and institutions

\begin{tabular}{lll}
\hline No. & Institutions & Investigators \\
\hline 1 & Ohtsuka Eye Hospital & Makoto Higuchi \\
2 & Mitani Eye Clinic & Kiichiro Mitani \\
3 & Muramatsu Eye Clinic & Tomoyuki Muramatsu \\
4 & Nakajima Eye Clinic & Toru Nakajima \\
5 & Kikukawa Eye Clinic & Koichiro Ikeda \\
6 & Tokai Eye Clinic & Yoshihide Nakai \\
7 & Kitano Hospital & Isao Saito \\
8 & Nishi Eye Hospital & Hiroki Iwanishi \\
9 & Hirota Eye Clinic & Atsushi Hirota \\
10 & Ohshima Hospital of Ophthalmology & Nobuyuki Yabe \\
11 & Hayashi Eye Hospital & Ken Hayashi \\
\hline
\end{tabular}

cells, flare, or ocular pain in the operative eye at the screening examination, had planned multiple surgical procedures, exfoliation syndrome, ocular trauma, inflammatory eye disease, diabetic retinopathy which needed medical treatment, and uncontrolled diabetes mellitus, or had grade 3 or higher cataracts according to Emery-Little classification [3].

\section{Examination items and schedule}

The examination schedule is shown in Table 2. Best-corrected visual acuity (BCVA) and intraocular pressure (IOP) measurement, ocular pain assessment, slit lamp examination, and laser flare cell meter (LFCM) measurement were performed before and 1, 3, 7, and 14 days after surgery. A fundus examination was performed before and 7 and 14 days after surgery. Blood pressure/pulse rate measurement was performed before and at the day of surgery and 1, 3, 7, and 14 days after surgery. A laboratory examination was performed before and 14 days after surgery.

\section{Efficacy evaluation}

The grading criteria and scale for clinical symptom and signs are summarized in Table 3 . The criteria and scale are the same as previous analysis of nepafenac [4-6]. Patients who received the test drug, completed surgery, and had at least one follow-up visit were included in the intention-to-treat (ITT) analyses. Primary efficacy analyses were conducted on the ITT data set. The primary efficacy variables were the cure rate (the percentage of subjects with an aqueous cell score + aqueous flare score $=$ 0 ) at day 14 after surgery and the ocular pain-free rate (the percentage of subjects with an ocular pain score of 0 ) at all postoperative visits. Also, the cure rate and the ocular 
Table 2 The examination schedule

\begin{tabular}{|c|c|c|c|c|c|c|c|}
\hline \multirow{2}{*}{ Tests and observations } & Pre-surgery & \multirow{2}{*}{$\begin{array}{l}\text { Surgery } \\
\text { (Day 0) }\end{array}$} & \multicolumn{5}{|c|}{ Post-surgery } \\
\hline & Baseline & & Day 1 & Day 3 & Day 7 & Day 14 & $\begin{array}{c}\text { Study } \\
\text { discontinuation }\end{array}$ \\
\hline Corrected visual acuity & $\mathrm{o}^{\mathrm{a}}$ & & $o^{b}$ & $\mathrm{o}^{\mathrm{b}}$ & $o^{b}$ & $0^{a}$ & $\mathrm{o}^{\mathrm{a}}$ \\
\hline Intraocular pressure & $\circ^{a}$ & & $\mathrm{o}^{\mathrm{b}}$ & $\mathrm{o}^{\mathrm{b}}$ & $\mathrm{o}^{\mathrm{b}}$ & $\circ^{a}$ & $0^{a}$ \\
\hline Fundus examination & $0^{a}$ & & & & $0^{b}$ & $0^{a}$ & $\circ^{a}$ \\
\hline Slit lamp examination & $0^{a}$ & & $\mathrm{o}^{\mathrm{b}}$ & $0^{b}$ & $0^{b}$ & $0^{a}$ & $\mathrm{o}^{\mathrm{a}}$ \\
\hline Ocular pain assessment & $\mathrm{o}^{\mathrm{b}}$ & & $o^{b}$ & $o^{b}$ & $\mathrm{o}^{\mathrm{b}}$ & $\mathrm{o}^{\mathrm{b}}$ & $0^{b}$ \\
\hline $\begin{array}{l}\text { Blood pressure } \\
\text { and pulse rate }\end{array}$ & 0 & ० & ○ & & ० & ० & ० \\
\hline Laser flare cell meter & $\mathrm{o}^{\mathrm{b}}$ & & $\mathrm{o}^{\mathrm{b}}$ & $\mathrm{o}^{\mathrm{b}}$ & $\mathrm{o}^{\mathrm{b}}$ & $\mathrm{o}^{\mathrm{b}}$ & $\mathrm{o}^{\mathrm{b}}$ \\
\hline Laboratory examination & ○ & & & & & ○ & ० \\
\hline $\begin{array}{l}\text { Instillation of the } \\
\text { investigational product }\end{array}$ & \multicolumn{6}{|c|}{ (-Day 1 - Day 14) } & \\
\hline Adverse events & & o & o & o & $c$ & ० & ० \\
\hline
\end{tabular}

${ }^{a}$ Both eyes

${ }^{\mathrm{b}}$ Study (operative) eye

Table 3 Grading criteria for clinical symptom and signs

\section{Grading criteria}

\begin{tabular}{|c|c|}
\hline \multirow[t]{6}{*}{ Ocular pain } & 0: None-absence of pain \\
\hline & 1: Trace—-slight sensation of pain or discomfort \\
\hline & 2: Mild—mild, tolerable aching of the eye \\
\hline & 3: Moderate - moderate and prolonged aching sufficient to require the use of analgesics \\
\hline & 4: Moderately severe - prolonged intense aching requiring the use of analgesics \\
\hline & 5: Severe - prolonged sharp ocular or periocular pain \\
\hline \multirow[t]{5}{*}{ Flare } & Use a $1 \mathrm{~mm}$ wide beam of the slit lamp aimed at the center of the pupil \\
\hline & 0: None - no visible flare when compared with the normal eye \\
\hline & $\begin{array}{l}\text { 1: Mild—flare visible against dark pupillary background but not visible against iris } \\
\text { background }\end{array}$ \\
\hline & $\begin{array}{l}\text { 2: Moderate-flare is visible with the slit lamp beam aimed onto the iris surface as } \\
\text { well as the dark pupillary background }\end{array}$ \\
\hline & $\begin{array}{l}\text { 3: Severe very dense flare. May also present as a "hazy" appearance of anterior } \\
\text { segment structures when viewed with low power magnification of the slit lamp. } \\
\text { Presents as a pronounced Tyndall effect }\end{array}$ \\
\hline \multirow[t]{6}{*}{ Cell } & $\begin{array}{l}\text { Use narrow slit beam ( } 0.5 \mathrm{~mm} \text { in width and at least } 8 \mathrm{~mm} \text { in length) at maximum } \\
\text { luminance. Pigment and red blood cells are to be ignored. }\end{array}$ \\
\hline & 0: None \\
\hline & 1: 1 to 5 cells \\
\hline & 2: 6 to 15 cells \\
\hline & 3: 16 to 30 cells \\
\hline & 4: Greater than 30 cells \\
\hline
\end{tabular}


Table 4 Demographic data (ITT)

\footnotetext{
${ }^{\text {a }}$ From Chi-square
}

\begin{tabular}{|c|c|c|c|c|c|c|c|}
\hline & \multicolumn{2}{|c|}{ Total } & \multicolumn{2}{|c|}{ Nepafenac group } & \multicolumn{2}{|c|}{ Placebo group } & \multirow[t]{2}{*}{$P$ value } \\
\hline & $N$ & $\%$ & $N$ & $\%$ & $N$ & $\%$ & \\
\hline Total & 211 & 100.0 & 106 & 50.2 & 105 & 49.8 & \\
\hline \multicolumn{8}{|l|}{ Gender } \\
\hline Male & 98 & 46.4 & 49 & 46.2 & 49 & 46.7 & \multirow[t]{2}{*}{0.9489} \\
\hline Female & 113 & 53.6 & 57 & 53.8 & 56 & 53.3 & \\
\hline \multicolumn{8}{|l|}{ Age } \\
\hline 18 to 64 years & 59 & 28.0 & 24 & 22.6 & 35 & 33.3 & \multirow[t]{2}{*}{0.0836} \\
\hline$\geq 65$ years & 152 & 72.0 & 82 & 77.4 & 70 & 66.7 & \\
\hline \multicolumn{8}{|c|}{ Emery's classification } \\
\hline 1 & 50 & 23.7 & 28 & 26.4 & 22 & 21.0 & \multirow[t]{2}{*}{0.3508} \\
\hline 2 & 161 & 76.3 & 78 & 73.6 & 83 & 79.0 & \\
\hline
\end{tabular}

pain-free rate at each postoperative visit were compared between two groups. The secondary variables were aqueous cell score, aqueous flare score, cell count, flare value, and the treatment failure rate (the percentage of subjects with either an aqueous cell score or an aqueous flare score of 3 or more, or an ocular pain score of 4 or more) at each postoperative visit. Cell count and flare value were measured with LFCM.

Table 5 Demographic data by institution (ITT)

\begin{tabular}{|c|c|c|c|c|c|c|c|c|c|c|c|c|c|c|}
\hline & & & \multicolumn{4}{|c|}{ Gender } & \multicolumn{4}{|c|}{ Age } & \multicolumn{4}{|c|}{ Emery's classification } \\
\hline & & & \multicolumn{2}{|c|}{ Male } & \multicolumn{2}{|c|}{ Female } & \multicolumn{2}{|c|}{$<65$} & \multicolumn{2}{|c|}{$\geq 65$} & \multicolumn{2}{|l|}{1} & \multicolumn{2}{|l|}{2} \\
\hline & & & $N$ & $\%$ & $N$ & $\%$ & $N$ & $\%$ & $N$ & $\%$ & $N$ & $\%$ & $N$ & $\%$ \\
\hline \multirow[t]{2}{*}{ Total } & & Nepafenac & 49 & 46.2 & 57 & 53.8 & 24 & 22.6 & 82 & 77.4 & 28 & 26.4 & 78 & 73.6 \\
\hline & & Placebo & 49 & 46.7 & 56 & 53.3 & 35 & 33.3 & 70 & 66.7 & 22 & 21.0 & 83 & 79.0 \\
\hline \multirow[t]{22}{*}{ Investigator no. } & 1 & Nepafenac & 4 & 66.7 & 2 & 33.3 & 2 & 33.3 & 4 & 66.7 & 4 & 66.7 & 2 & 33.3 \\
\hline & & Placebo & 2 & 33.3 & 4 & 66.7 & 3 & 50.0 & 3 & 50.0 & 5 & 83.3 & 1 & 16.7 \\
\hline & 2 & Nepafenac & 5 & 41.7 & 7 & 58.3 & 3 & 25.0 & 9 & 75.0 & 5 & 41.7 & 7 & 58.3 \\
\hline & & Placebo & 6 & 50.0 & 6 & 50.0 & 1 & 8.3 & 11 & 91.7 & 5 & 41.7 & 7 & 58.3 \\
\hline & 3 & Nepafenac & 5 & 33.3 & 10 & 66.7 & 2 & 13.3 & 13 & 86.7 & 0 & 0.0 & 15 & 100.0 \\
\hline & & Placebo & 6 & 40.0 & 9 & 60.0 & 2 & 13.3 & 13 & 86.7 & 0 & 0.0 & 15 & 100.0 \\
\hline & 4 & Nepafenac & 6 & 75.0 & 2 & 25.0 & 0 & 0.0 & 8 & 100.0 & 6 & 75.0 & 2 & 25.0 \\
\hline & & Placebo & 4 & 50.0 & 4 & 50.0 & 2 & 25.0 & 6 & 75.0 & 5 & 62.5 & 3 & 37.5 \\
\hline & 5 & Nepafenac & 7 & 43.8 & 9 & 56.3 & 2 & 12.5 & 14 & 87.5 & 0 & 0.0 & 16 & 100.0 \\
\hline & & Placebo & 7 & 43.8 & 9 & 56.3 & 5 & 31.3 & 11 & 68.8 & 0 & 0.0 & 16 & 100.0 \\
\hline & 6 & Nepafenac & 3 & 60.0 & 2 & 40.0 & 1 & 20.0 & 4 & 80.0 & 0 & 0.0 & 5 & 100.0 \\
\hline & & Placebo & 2 & 33.3 & 4 & 66.7 & 3 & 50.0 & 3 & 50.0 & 0 & 0.0 & 6 & 100.0 \\
\hline & 7 & Nepafenac & 2 & 22.2 & 7 & 77.8 & 2 & 22.2 & 7 & 77.8 & 2 & 22.2 & 7 & 77.8 \\
\hline & & Placebo & 3 & 50.0 & 3 & 50.0 & 2 & 33.3 & 4 & 66.7 & 2 & 33.3 & 4 & 66.7 \\
\hline & 8 & Nepafenac & 3 & 37.5 & 5 & 62.5 & 3 & 37.5 & 5 & 62.5 & 2 & 25.0 & 6 & 75.0 \\
\hline & & Placebo & 4 & 44.4 & 5 & 55.6 & 4 & 44.4 & 5 & 55.6 & 1 & 11.1 & 8 & 88.9 \\
\hline & 9 & Nepafenac & 5 & 55.6 & 4 & 44.4 & 2 & 22.2 & 7 & 77.8 & 2 & 22.2 & 7 & 77.8 \\
\hline & & Placebo & 5 & 55.6 & 4 & 44.4 & 5 & 55.6 & 4 & 44.4 & 2 & 22.2 & 7 & 77.8 \\
\hline & 10 & Nepafenac & 4 & 33.3 & 8 & 66.7 & 3 & 25.0 & 9 & 75.0 & 6 & 50.0 & 6 & 50.0 \\
\hline & & Placebo & 6 & 50.0 & 6 & 50.0 & 5 & 41.7 & 7 & 58.3 & 1 & 8.3 & 11 & 91.7 \\
\hline & 11 & Nepafenac & 5 & 83.3 & 1 & 16.7 & 4 & 66.7 & 2 & 33.3 & 1 & 16.7 & 5 & 83.3 \\
\hline & & Placebo & 4 & 66.7 & 2 & 33.3 & 3 & 50.0 & 3 & 50.0 & 1 & 16.7 & 5 & 83.3 \\
\hline
\end{tabular}


Table 6 Cure rate at each study visit (ITT)

Test $=$ Chi-square (Fisher's exact test if $N<5$ )

${ }^{\text {a }}$ One patient missing cure data

\section{Safety evaluation}

All patients receiving the test drug were included in the safety analysis. Safety evaluation included incidence of adverse events (AEs), blood pressure/pulse rate, laboratory tests, BCVA, IOP, slit lamp examination (bulbar conjunctival injection, corneal edema, and chemosis), and fundus examination (retina, macula lutea, choroid, and optic nerve).

\section{Statistical analysis}

For the primary variables of cure rate at day 14 and the ocular pain-free rate at all postoperative visits, a Chisquare test of independence was conducted to assess the superiority of nepafenac relative to placebo. Multiplicity adjustment for the primary endpoints was made by sequential testing with fixed sequences, in which the cure rate was analyzed first followed by the ocular pain-free rate. And a Chi-square test or a Fisher's exact test was performed for the cure rate and the ocular pain-free rate at each study visit.

The analysis of aqueous cells score, flare scores, cell counts, and flare value was conducted with a repeated measures analysis of variance at postoperative visits. A two-sample $t$ test was used for the comparisons in aqueous cells score and flare score at baseline between two groups. The comparisons between nepafenac and placebo in treatment failures at each postoperative visit were made using nonlinear mixed model with maximum likelihood estimation from NLMixed procedure of SAS software. Demographics data were compared between two groups using by a Chi-square test. A $P$ value less than 0.05 indicated statistical significance. Data analyses were performed using SAS software, version 9.1.

\section{Results}

Patient population and demographics

Two hundred fifteen patients, 108 treated with nepafenac and 107 treated with placebo, were enrolled in this study. One patient discontinued prior to the use of the study medication for patient decision. Two hundred fourteen remaining patients received at least one dose of test drug and were therefore included in the safety analysis. Three of 214 patients discontinued from the study prior to or at the time of surgery for patient decision $(n=1)$, the use of NSAIDs $(n=1)$ and investigator decision due to surgical difficulties. These three patients were excluded in the ITT population. A total of 211 patients, 106 treated with nepafenac and 105 treated with placebo were included in the ITT population.

The demographics data for the patients included in the ITT data set are summarized in Table 4, and the demographics data by institution are showed in Table 5 . As indicated in Table 4, there were no statistically significant differences in gender, age, and Emery's classification between treatment groups.

\section{Efficacy}

There was a significant difference in cure rate at day 14 between nepafenac $(71.4 \%, 75 / 105)$ and placebo $(28.6 \%, 30 / 105)(P<0.0001)$, demonstrating the effectiveness of nepafenac in reducing postoperative inflammation (Table 6). When comparing cure rates at each visit, nepafenac achieved significantly higher cure rates than placebo at days 7 and $14(P<0.0001$ for days 7 and 14) (Table 6). The ocular pain-free rate was $96.2 \%(102 / 106)$ in the nepafenac group and $67.6 \%(71 / 105)$ in the placebo group, showing a significant difference between groups $(P<0.0001)$ (Table 7). The nepafenac group demonstrated significantly higher ocular pain-free rates than the placebo group at all postoperative visits $(P=0.0051$ for day $1, P=0.0003$ for day 3, $P=0.0002$ for day 7 , and $P=0.0051$ for day 14) (Table 8 ). In the nepafenac group, cell scores and flare scores measured at each postoperative visit decreased as time elapsed after surgery, showing the suppressive effect of

Table 7 Percent ocular pain free (ITT)

\begin{tabular}{llll}
\hline Treatment & Total & & Pain free \\
\cline { 3 - 4 } & $N$ & $N$ & $\%$ \\
\hline Nepafenac group & 106 & 102 & 96.2 \\
Placebo group & 105 & 71 & 67.6 \\
\hline
\end{tabular}

Test $=$ Chi-square, $P<0.0001$ 
Table 8 Percentage of patients with no pain at each study visit (ITT)

Test $=$ Chi-square

\begin{tabular}{|c|c|c|c|c|c|c|c|c|c|}
\hline \multirow[t]{2}{*}{ Treatment } & \multirow[t]{2}{*}{ All $(N)$} & \multicolumn{2}{|c|}{ Day 1} & \multicolumn{2}{|c|}{ Day 3} & \multicolumn{2}{|c|}{ Day 7} & \multicolumn{2}{|c|}{ Day 14} \\
\hline & & $N$ & $\%$ & $N$ & $\%$ & $N$ & $\%$ & $N$ & $\%$ \\
\hline Nepafenac group & 106 & 103 & 97.2 & 104 & 98.1 & 103 & 97.2 & 103 & 97.2 \\
\hline Placebo group & 105 & 91 & 86.7 & 88 & 83.8 & 85 & 81.0 & 91 & 86.7 \\
\hline$P$ value & & & 0.0051 & & 0.0003 & & 0.0002 & & 0.0051 \\
\hline
\end{tabular}

nepafenac on postoperative inflammation. In contrast, no marked decrease was observed in either the cell or flare scores in the placebo group. Significant intergroup differences were observed in the cell score on day 7 and subsequent visits $(P<0.0001$ for days 7 and 14) and in the flare score on day 3 and subsequent visits $(P=0.0041$ for day 3 and $P<0.0001$ for days 7 and 14) (Tables 9 and 10). Postoperative cell counts and flare values were measured with LFCM. Decreases in both cell counts and flare values were observed on day 3 and subsequent visits in the nepafenac group, whereas increases in both variables were observed on day 3 in the placebo group. Significant intergroup differences were observed in cell counts and flare values on day 3 and subsequent visits (Tables 11 and 12).

The incidence of treatment failures 14 days after surgery was $1.9 \%(2 / 106)$ in the nepafenac group and $8.6 \%(9 / 105)$ in the placebo group. There were more subjects who had no response to treatment in the placebo group than in the nepafenac group, although no significant difference was observed between groups (Table 13).

\section{Safety}

A total of 26 AEs were reported in 21 subjects (19.6\%) in the nepafenac group and 31 AEs were reported in 24 subjects $(22.4 \%)$ in the placebo group. Two AEs in the nepafenac group and six AEs in the placebo group were regarded as adverse reactions (ADRs) for which the causal relation could not be ruled out. The ADRs reported in the nepafenac group were foreign body sensation in the eyes in one subject $(0.9 \%)$ and eye discharge in one subject $(0.9 \%)$, both of which were mild and non-serious. The ADRs reported in the placebo group were eye pruritus in one subject $(0.9 \%)$, foreign body sensation in the eyes in one subject $(0.9 \%)$ subject, eye irritation in two subjects (1.9\%), and increased lacrimation in two subjects $(1.9 \%)$, all of which were non-serious. All of the ADRs were mild in severity, except for moderate foreign body sensation in the eyes reported in one subject. In the nepafenac group, no clinically relevant findings were obtained in other examinations for safety evaluations including laboratory tests, blood pressure/pulse rate, BCVA, IOP, slit lamp examination, and fundus examination.

\section{Discussion}

In Japan, the ophthalmic preparations of steroids or NSAIDs are used for the treatment of postoperative inflammation following cataract surgery. NSAIDs are also used for the prevention of postoperative cystoid macular edema (CME). Diclofenac sodium and bromfe-
Table 9 Aqueous cells score by treatment and visit (ITT)

Baseline $P$ value is from $t$ test; non-baseline $P$ values are LSMeans by visit; test $=$ repeated measure ANOVA, main effect of treatment $P<0.0001$; treatment by visit interaction $P<0.0001$

Min minimum, Max maximum, Std standard deviation

\begin{tabular}{lllllll}
\hline & & Baseline & Day 1 & Day 3 & Day 7 & Day 14 \\
\hline Nepafenac group & Mean & 0.0 & 1.3 & 0.9 & 0.5 & 0.3 \\
& Std & 0.0 & 0.6 & 0.7 & 0.6 & 0.6 \\
& $N$ & 106 & 105 & 105 & 105 & 105 \\
& Min & 0 & 0 & 0 & 0 & 0 \\
Placebo group & Max & 0 & 4 & 4 & 4 & 4 \\
& Mean & 0.0 & 1.2 & 1.0 & 1.0 & 0.9 \\
& Std & 0.0 & 0.5 & 0.7 & 0.9 & 0.9 \\
& $N$ & 105 & 105 & 105 & 105 & 105 \\
$P$ value & Min & 0 & 0 & 0 & 0 & 0 \\
\hline
\end{tabular}


Table 10 Flare score by treatment and visit (ITT)

Baseline $P$ value is from $t$ test; non-baseline $P$ values are LSMeans by visit; test $=$ repeated measure ANOVA, main effect of treatment $P<0.0001$; treatment by visit interaction $P<0.0001$

Min minimum, Max maximum, Std standard deviation

\begin{tabular}{lllllll}
\hline & & Baseline & Day 1 & Day 3 & Day 7 & Day 14 \\
\hline Nepafenac group & Mean & 0.0 & 0.9 & 0.5 & 0.3 & 0.1 \\
& Std & 0.0 & 0.6 & 0.6 & 0.5 & 0.3 \\
& $N$ & 106 & 105 & 105 & 105 & 105 \\
& Min & 0 & 0 & 0 & 0 & 0 \\
Placebo group & Max & 0 & 2 & 2 & 2 & 2 \\
& Mean & 0.0 & 0.9 & 0.7 & 0.8 & 0.6 \\
& Std & 0.0 & 0.5 & 0.7 & 0.8 & 0.8 \\
& $N$ & 105 & 105 & 105 & 105 & 105 \\
$P$ value & Min & 0 & 0 & 0 & 0 & 0 \\
\hline & Max & 0 & 2 & 3 & 3 & 3 \\
& & N/A & 0.5793 & 0.0041 & $<0.0001$ & $<0.0001$ \\
\hline
\end{tabular}

nac have been shown to reduce postoperative inflammation [7-10]. Some studies have shown that aqueous flare values in the early postoperative period are even lower in those treated with diclofenac sodium than in those treated with steroids [11, 12]. Other studies have demonstrated that NSAIDs are effective in preventing postoperative CME [13-16], in which an ophthalmic NSAID was administered for several months after cataract surgery. Nepafenac is a prodrug metabolized into its active form, amfenac. Ex vivo inhibition of prostaglandin synthesis by nepafenac/amfenac was significantly greater and of longer duration than diclofenac [2]. And nepafenac had sixfold greater corneal penetration than diclofenac [17]. Amfenac was the more potent COX-2 inhibitor than bromfenac and ketorolac. And the combined area under the curve of nepafenac and amfenac was higher than the bromfenac and ketorolac [1].

In this study, nepafenac expected to prevent postoperative inflammation and ocular pain, was administered as a monotherapy to patients undergoing cataract surgery, and its efficacy and safety in the management of postoperative inflammation and ocular pain were compared with those of a placebo. The subjects were Japanese patients with cataracts who were undergoing cataract surgery with PEA and IOL implantation. Evaluations were based on cure rates 14 days after surgery and ocular pain-free rates during the first 14 days after surgery. The cure rate was $71.4 \%$ in the nepafenac group and $28.6 \%$ in the placebo group, showing a significant difference between groups. Those who achieved cures in the placebo group appeared to have undergone spontaneous resolution of postoperative inflammation, as indicated by a gradual increase in cure rates over the course of treatment. In contrast, the nepafenac group demonstrated higher cure rates than those in the placebo group, with significant intergroup differences observed on days 7 and 14 postoperatively. This study revealed significant differences in cure rates between nepafenac and placebo over the course of treatment, which was consistent with the results of a study conducted in the USA using the same evaluation [4].
Table 11 Cell count measured by LFCM by treatment and visit (ITT)

Non-baseline $P$ values are LSMeans by visit; test $=$ repeated measure ANOVA, main effect of treatment $P=0.0011$; treatment by visit interaction $P=0.0186$; cell count was measured by laser flare cell meter at six sites

Min minimum, Max maximum, Std standard deviation

\begin{tabular}{llcccc}
\hline & & Day 1 & Day 3 & Day 7 & Day 14 \\
\hline Nepafenac group & Mean & 39.2 & 19.8 & 9.7 & 6.0 \\
& Std & 79.2 & 25.1 & 11.2 & 9.8 \\
& $N$ & 54 & 54 & 54 & 54 \\
Placebo group & Min & 0.0 & 0.0 & 0.0 & 0.0 \\
& Max & 428.7 & 116.4 & 52.7 & 65.3 \\
& Mean & 40.4 & 55.3 & 32.2 & 24.1 \\
& Std & 52.8 & 66.2 & 37.3 & 31.4 \\
$P$ value & $N$ & 53 & 54 & 54 & 54 \\
& Min & 0.0 & 0.0 & 0.0 & 0.0 \\
& Max & 312.2 & 311.2 & 177.3 & 128.0 \\
& & 0.8738 & $<0.0001$ & 0.0107 & 0.0394 \\
\hline
\end{tabular}


Table 12 Flare value measured by LFCM by treatment and visit (ITT)

Non-baseline $P$ values are LSMeans by visit; test $=$ repeated measure ANOVA, main effect of treatment $P<0.0001$; treatment by visit interaction $P<0.0001$

Min minimum, Max maximum, Std standard deviation

\begin{tabular}{llcccc}
\hline & & Day 1 & Day 3 & Day 7 & Day 14 \\
\hline Nepafenac group & Mean & 20.6 & 20.6 & 13.4 & 11.4 \\
& Std & 24.6 & 40.9 & 12.2 & 9.1 \\
& $N$ & 101 & 103 & 103 & 103 \\
Placebo group & Min & 0.5 & 0.3 & 0.4 & 0.3 \\
& Max & 153.2 & 396.7 & 57.8 & 57.8 \\
& Mean & 24.3 & 47.5 & 65.6 & 52.0 \\
& Std & 34.4 & 49.8 & 77.7 & 69.9 \\
$P$ value & $N$ & 101 & 104 & 104 & 104 \\
& Min & 1.8 & 2.5 & 2.5 & 1.5 \\
& Max & 307.6 & 333.9 & 479.7 & 479.7 \\
& & 0.6201 & $<0.0001$ & $<0.0001$ & $<0.0001$ \\
\hline
\end{tabular}

The use of LFCM in the evaluation of postoperative inflammation following cataract surgery has been described in many studies [18-20]. LFCM enables assessment of the degree of inflammation by quantitatively measuring such parameters as white blood cell count and protein concentration in the aqueous humor. This study also included secondary endpoints that were evaluated with LFCM. Aqueous cell counts and aqueous flare values as measured with LFCM were significantly lower in the nepafenac than in the placebo group. The mean flare value in the placebo group reached its peak on day 7 while no postoperative increase in flare values was observed in the nepafenac group. Cell scores and flare scores determined by slit lamp biomicroscopy and flare values and cell counts measured with LFCM showed similar patterns of changes over time from day 3 and thereafter, demonstrating the appropriateness of the efficacy evaluation based on cell scores and flare scores determined by slit lamp biomicroscopy and the efficacy of nepafenac in the management of postoperative inflammation.

Since postoperative inflammation following intraocular surgery contributes to the development of CME, it is very important to reduce or resolve postoperative inflammation. In this study, evaluations were only performed up to 2 weeks after surgery, and thus the preventative effect of nepafenac on CME was not examined. However, the fact that the cure rate of nepafenac was significantly higher than placebo implies that nepafenac is likely to be effective in preventing the development of CME.
This study also examined the ocular pain after cataract surgery. The pain-free rate was $96.2 \%$ in the nepafenac group and $67.6 \%$ in the placebo group, showing a significant difference between groups. Most subjects in the nepafenac group complained of no ocular pain throughout the study period while more than $30 \%$ of the subjects in the placebo group complained of ocular pain. These findings also suggest the need for the postoperative use of agents with an analgesic effect, such as nepafenac $0.1 \%$, in clinical practice.

Reported AEs associated with ophthalmic NSAIDs include diffuse superficial keratitis, corneal erosion, and corneal epithelium disorder, and more serious AEs include corneal ulcer and corneal perforation [21]. In this study, no clinically significant AEs associated with nepafenac were reported, and the incidences of AEs and ADRs in the nepafenac group were lower than those in the placebo group, demonstrating the favorable safety profile of nepafenac.

\section{Conclusion}

Nepafenac ophthalmic suspension $0.1 \%$ is significantly more effective than the placebo in the management of postoperative inflammation and ocular pain following cataract surgery and thus is considered an essential NSAID in ophthalmic surgery.
Table 13 Incidence of treatment failures at each study visit (ITT)

NLMixed model $P=0.6151$; main effect of treatment; failure defined as aqueous cells score $\geq 3$ or aqueous flare score $=3$ or ocular pain score $\geq 4$

\begin{tabular}{|c|c|c|c|c|c|c|c|c|c|}
\hline \multirow[t]{2}{*}{ Treatment } & \multirow{2}{*}{$\begin{array}{l}\text { Total } \\
N\end{array}$} & \multicolumn{2}{|c|}{ Day 1} & \multicolumn{2}{|c|}{ Day 3} & \multicolumn{2}{|c|}{ Day 7} & \multicolumn{2}{|c|}{ Day 14} \\
\hline & & $N$ & $\%$ & $N$ & $\%$ & $N$ & $\%$ & $N$ & $\%$ \\
\hline Nepafenac group & 106 & 2 & 1.9 & 2 & 1.9 & 2 & 1.9 & 2 & 1.9 \\
\hline Placebo group & 105 & 0 & 0.0 & 1 & 1.0 & 9 & 8.6 & 9 & 8.6 \\
\hline$P$ value & & & 0.5467 & & 0.3974 & & 0.2001 & & 0.2236 \\
\hline
\end{tabular}


Acknowledgments This study was funded by Alcon Japan Limited.

Open Access This article is distributed under the terms of the Creative Commons Attribution License which permits any use, distribution and reproduction in any medium, provided the original author(s) and source are credited.

\section{References}

1. Walters T, Raizman M, Ernest P, Gayton J, Lehmann R (2007) In vivo pharmacokinetics and in vitro pharmacodynamics of nepafenac, amfenac, ketorolac, and bromfenac. J Cataract Refract Surg 33:1539-1545

2. Gamache DA, Graff G, Brady MT, Spellman JM, Yanni JM (2000) Nepafenac, a unique nonsteroidal prodrug with potential utility in the treatment of trauma-induced ocular inflammation: I. Assessment of anti-inflammatory efficacy. Inflammation 24:357-370

3. Emery JM, Little JH (1979) Phacoemulsification and aspiration of cataract: surgical techniques, complications, and results. Mosby, St Louis, pp 45-48

4. Lane SS, Modi SS, Lehmann RP, Holland EJ (2007) Nepafenac ophthalmic suspension $0.1 \%$ for the prevention and treatment of ocular inflammation associated with cataract surgery. J Cataract Refract Surgery 33:53-58

5. Nardi M, Lobo C, Bereczki A, Cano J, Zagato E, Potts S, Sullins G, Notivol R, for the International C-04-65 Study Group (2007) Analgesic and anti-inflammatory effectiveness of nepafenac $0.1 \%$ for cataract surgery. Clin Ophthalmol 1:527-533

6. Maxwell WA, Reiser HJ, Stewart RH, Cavanagh HD, Walters TR, Sager DP, Meuse PA, the Nepafenac Study Group (2008) Nepafenac dosing frequency for ocular pain and inflammation associated with cataract surgery. J Ocul Pharmacol Ther 24:593-599

7. Reddy MS, Suneetha N, Thomas RK, Battu RR (2000) Topical diclofenac sodium for treatment of postoperative inflammation in cataract surgery. Indian J Ophthalmol 48:223-226

8. el-Harazi SM, Ruiz RS, Feldman RM, Villanueva G, Chuang AZ (1998) A randomized double-masked trial comparing ketorolac tromethamine $0.5 \%$, diclofenac sodium $0.1 \%$, and prednisolone acetate $1 \%$ in reducing post-phacoemulsification flare and cells. Ophthalmic Surg Lasers 29:539-544

9. Demco TA, Sutton H, Demco CJ, Raj PS (1997) Topical diclofenac sodium compared with prednisolone acetate after phacoemulsification-lens implant surgery. Eur J Ophthalmol $7: 236-240$
10. Donnenfeld ED, Holland EJ, Sewart RH, Gow JA, Grillone LR, Bromfenac Ophthalmic Solution 0.09\%(Xibrom) Study group (2007) Bromfenac ophthalmic solution 0.09\%(Xibrom) for postoperative ocular pain and inflammation. Ophthalmology 114:1653-1662

11. Herbort CP, Jauch A, Othenin-Girard P, Tritten JJ, Fsadni M (2000) Diclofenac drops to treat inflammation after cataract surgery. Acta Ophthalmol Scand 78:421-424

12. Othenin-Girard P, Tritten JJ, Pittet N, Herbort CP (1994) Dexamethasone versus diclofenac sodium eyedrops to treat inflammation after cataract surgery. J Cataract Refract Surg 20:9-12

13. Miyake K, Sakamura S, Miura H (1980) Long-term follow up study on the prevention of aphakic cystoid macular edema by topical indomethacin. Br J Ophthalmol 64:324-328

14. Rossetti L, Bujtar E, Castoldi D, Torrazza C, Orzalesi N (1996) Effectiveness of diclofenac eyedrops in reducing inflammation and the incidence of cystoid macular edema after cataract surgery. J Cataract Refract Surg 22(Suppl 1):794-799

15. Flach AJ, Stegman RC, Graham J, Kruger LP (1990) Prophylaxis of aphakic cystoid macular edema without corticosteroids, a paired-comparison, placebo-controlled double-masked study. Ophthalmology 97:1253-1258

16. Miyake K, Masuda K, Shirato S, Oshika T, Eguchi K, Hoshi H, Majima Y, Kimura W, Hayashi F (2000) Comparison of diclofenac and fluorometholone in preventing cystoid macular edema after small incision cataract surgery: a multicentered prospective trial. Jpn J Ophthalmol 44:58-67

17. Ke T-L, Graff G, Spellman JM, Yanni JM (2000) Nepafenac, a unique nonsteroidal prodrug with potential utility in the treatment of trauma-induced ocular inflammation: II. In vitro bioactivation and permeation of external ocular barriers. Inflammation 24:371-384

18. Sawa M, Tsurimaki Y, Tsuru T, Shimizu H (1988) New quantitative method to determine protein concentration and cell numbr in aqueous in vivo. Jpn J Ophthalmol 32:132-142

19. Oshika T, Yoshimura K, Miyata N (1992) Postsurgical inflammation after phacoemulsification and extracapsular ectraction with soft or conventional intraocular lens implantaion. J Cataract Refract Surg 18:356-361

20. Shah SM, Spalton DJ (1994) Changes in anterior chamber flare and cell following cataract surgery. $\mathrm{Br} \mathrm{J}$ Ophthalmol 78:91-94

21. Guidera AC, Luchs JI, Udell IJ (2001) Keratitis, ulceration, and perforation associated with topical nonsteroidal anti-inflammatory drugs. Ophthalmology 108:936-944 